\title{
REFERENCES
}

BEARDMORE, J. A. I96o. Developmental stability in constant and fluctuating temperatures. Heredity, 14, 4I I-422.

GIBSON, J. B., AND THODAY, J. M. I959. Recombinational lethals in a polymorphic population. Nature, I84, I593-I594.

MANN, M. C. I923. The occurrence and hereditary behaviour of two new dominant mutations in an inbred strain of Drosophila melanogaster. Genetics, 8, 27-36.

PARSONS, P. A. I96 I. Fly size, emergence time and sternopleural chaeta number in Drosophila. Heredity (in press).

PARSONs, P. A., AND KROMAN, R. A. I96o. Melanin inhibitors and the ebony locus in Drosophila melanogaster. Heredity, ${ }_{5}, 30 \mathrm{I}-3 \mathrm{I} 4$.

PLUNKETT, C. R. I926. The interaction of genetic and environmental factors in development. 7. Exp. Zool., 46 , 18 $1-245$.

REEVE, E. C. R. I96o. Some genetic tests on asymmetry of sternopleural chaeta number in Drosophila. Genet. Res., I, I5 I-I 72.

STERN, C. 1954. Two or three bristles. American Scientist, 42, 2 1 3-247.

THODAY, J. M. 1958. Homeostasis in a selection experiment. Heredity, I2, 40I-4I5. ThODAY, J. M., AND BOAM, T. B. I 959. Effects of disruptive selection II. Polymorphism and divergence without isolation. Heredity, $\mathrm{I}_{3}, 205-2 \mathrm{I} 8$.

THODAY, J. M., AND BOAM, т. в. I96r. Regular responses to selection I. Description of responses. Genet. Res., 2, I6I-I 76.

\section{SEGREGATION IN TETRAPLOID BLACKBERRIES}

\author{
G. HASKELL
}

Scottish Horticultural Research Institute, Invergowrie, by Dundee

and

J. HILL

A.R.C. Unit of Biometrical Genetics, Department of Genetics, University of Birmingham

\section{INTRODUCTION}

Received 20.iv.6r

Modern blackberry breeding is largely confined to improvements at the tetraploid level, and is particularly concerned with the production of early thornless types. The thornless character is controlled by a recessive gene which was originally given the symbol $A / a$ by Crane and Darlington (1932) ; but following the usage by Lewis (1939) of $S / s$ (= spineless) for the character in Rubus idaeus this latter symbol has now been generally adopted.

This character is particularly convenient for a study of tetraploid segregation in $\mathrm{F}_{2}$ progeny, since differences between the alleles $S$ and $s$ can be readily distinguished during the cotyledon stage of recently emerged seedlings. At this stage, the $S$ plants have glands along the edges of the cotyledons, whereas the homozygous recessive $s$ plants possess naked cotyledons. The amount of mis-classification is very low, being confined largely to seedlings with abnormal cotyledons and to very late germinators. Large populations can, therefore, be raised and classified.

Darlington and Crane (1932) examined the $F_{2}$ progeny from a cross 
between $R$. rusticanus (var, inermis) - with an unreduced egg cell $(n=14)$ and $R$. thyrsiger $(2 n=28)$ for segregation of the thornless character. Their results, based on a total segregating population of 872 seedlings, gave ratios similar to that expected for so-called "chromatid" segregation (20.8: I) instead of the $35:$ I predicted if " chromosome " segregation was operating.

In view of the relative ease with which large $F_{2}$ populations could be raised, it was decided to carry out a series of crosses designed to determine not only the $\mathrm{F}_{2}$ ratios, but also to see whether these ratios varied with the parents used.

Throughout these experiments the commercial tetraploid variety Merton Thornless $(2 n=28)$, which is nulliplex for the recessive $s$ gene, was used as the female parent. The three cultivated tetraploid thorned blackberries used as the pollen parents were Himalaya Giant $(R$. procerus), Edward Langley $(R$. calvatus) and Cut-Leaf $(R$. laciniatus). These three species are almost certainly $S S S S$ in constitution, as $\mathrm{F}_{1}$ progenies with Merton Thornless were all thorned.

\section{ANALYSIS AND RESULTS}

A preliminary analysis of the $\mathrm{F}_{2}$ ratios obtained for the thornless gene in the three crosses showed significant total deviations from both a $35:$ I and a $20 \cdot 8:$ i ratio. In order to test the consistency of the segregations within and between crosses (groups) it was necessary therefore to use the test devised by Brandt and Snedecor (see Mather, 195I). The resulting $\chi^{2}$ values clearly showed that heterogeneity was present both within and between groups (table I). By considering each of the three groups individually, the heterogeneity within groups was shown to be mainly attributable to the cross involving $R$. laciniatus (table 2). Whilst the omission of families 82 and 88 satisfactorily removed the heterogeneity from within this group, there was still heterogeneity between groups at the 5 per cent. level of significance. Inspection of table 3 indicates that the heterogeneity between groups is due chiefly to differences between $R$. calvatus and $R$. procerus with respect to the $S: s$ ratio, since $R$. laciniatus has an intermediate value.

After omitting families 82 and 88 , it was found that overall there was no longer a significant deviation from a $20.8:$ i ratio, although the cross involving $R$. calvatus did in fact differ from such an expectation at the 5 per cent. level of significance (table 4 ). The production of more thornless individuals than expected on the basis of a $35: 1$ ratio can only be due to a higher frequency of formation of recessive gametes, which in turn will depend on two factors ; the mean equational separation of the locus under consideration and the non-disjunction of adjacent chromosomes. The product of these, which estimates the amount of double reduction $(\alpha)$, can be calculated from the expectation of each of the two classes (see Mather, 1936 ; Fisher and Mather, 1943). Higher values of $\alpha$ indicate that recessive gametes were produced more often, resulting in the formation of a larger number of thornless individuals (table 3 ).

Turning to the two anomalous families, 82 and 88 , both of which showed such a marked deficiency of thornless plants, the values of $\alpha$ obtained for each family separately were negative and therefore meaningless. These two families would seem to pose a different problem from the remainder and therefore can be legitimately omitted from the present consideration. 
TABLE I

Tetraploid segregations in Rubus

\begin{tabular}{|c|c|c|c|c|c|c|c|c|}
\hline \multicolumn{3}{|c|}{$\begin{array}{c}\text { Merton Thornless } \times \\
R . \text { procerus }\end{array}$} & \multicolumn{3}{|c|}{$\begin{array}{c}\text { Merton-Thornless } \times \\
R . \text { calvatus }\end{array}$} & \multicolumn{3}{|c|}{$\begin{array}{c}\text { Merton Thornless } \times \\
R \text {. laciniatus }\end{array}$} \\
\hline $\begin{array}{l}\text { Family } \\
\text { no. }\end{array}$ & $\begin{array}{l}\text { No. of } s \\
\text { plants }\end{array}$ & Total & $\begin{array}{c}\text { Family } \\
\text { no. }\end{array}$ & $\begin{array}{l}\text { No. of } s \\
\text { plants }\end{array}$ & Total & $\begin{array}{c}\text { Family } \\
\text { no. }\end{array}$ & $\begin{array}{l}\text { No. of } s \\
\text { plants }\end{array}$ & Total \\
\hline $\begin{array}{l}59 \\
60 \\
66 \\
63 \\
62 \\
64 \\
67 \\
52 \\
65 \\
53 \\
57 \\
61 \\
51 \\
58\end{array}$ & $\begin{array}{r}\text { I4 } \\
24 \\
\text { I } 3 \\
\text { I } 3 \\
\text { I I } \\
4 \\
4 \\
9 \\
\text { I } 9 \\
\text { I } 4 \\
\text { I } 2 \\
7 \\
2 \\
\text { I } 9\end{array}$ & $\begin{array}{r}417 \\
622 \\
328 \\
3 \text { I } 5 \\
230 \\
83 \\
82 \\
\text { I } 72 \\
352 \\
255 \\
197 \\
\text { I I } 3 \\
30 \\
248\end{array}$ & $\begin{array}{l}75 \\
77 \\
69 \\
73 \\
72 \\
74 \\
71 \\
68 \\
76 \\
56 \\
\ldots \\
\ldots \\
\ldots \\
\cdots\end{array}$ & $\begin{array}{r}1 \\
2 \\
6 \\
4 \\
29 \\
8 \\
3 \\
4 \\
25 \\
18 \\
\ldots \\
\ldots \\
\ldots \\
\ldots\end{array}$ & $\begin{array}{r}77 \\
\text { I } 2 \text { I } \\
2 \text { I } 3 \\
\text { 1 } 38 \\
987 \\
269 \\
88 \\
87 \\
455 \\
298 \\
\ldots \\
\ldots \\
\ldots \\
\ldots\end{array}$ & $\begin{array}{l}82 \\
88 \\
80 \\
54 \\
84 \\
79 \\
86 \\
78 \\
85 \\
55 \\
83 \\
87 \\
81 \\
\ldots\end{array}$ & $\begin{array}{r}\text { I } \\
6 \\
2 \\
\text { I } 3 \\
7 \\
\text { I } 6 \\
8 \\
\text { I I } \\
8 \\
\text { 1 } 7 \\
9 \\
20 \\
\text { I } 6 \\
\ldots\end{array}$ & $\begin{array}{r}228 \\
475 \\
98 \\
504 \\
253 \\
497 \\
242 \\
332 \\
201 \\
371 \\
173 \\
316 \\
228 \\
\ldots\end{array}$ \\
\hline \multirow[t]{3}{*}{ Total } & 165 & 3444 & $\cdots$ & IOO & 2733 & $\cdots$ & 134 & 39 I 8 \\
\hline & \multicolumn{2}{|c|}{ Grand totals } & - & \multicolumn{2}{|c|}{399} & \multicolumn{2}{|c|}{ I 0,095} & \\
\hline & $\begin{array}{l}\chi^{2} \\
\text { Degr } \\
\text { Prob }\end{array}$ & $\begin{array}{l}\text { of free } \\
\text { lity }\end{array}$ & in & \multicolumn{2}{|c|}{$\begin{array}{c}\text { Within groups } \\
56.62 \\
34 \\
\text { o.0I-0.00 I }\end{array}$} & \multicolumn{2}{|c|}{$\begin{array}{c}\text { Between groups } \\
\qquad \begin{array}{c}9.93 \\
2 \\
\text { o.OI-0.0OI }\end{array}\end{array}$} & \\
\hline
\end{tabular}

TABLE 2

Test of within group heterogeneity for the $3 F_{2}$ progenies

\begin{tabular}{|c|c|c|c|}
\hline Group & $\chi^{2}$ & $\begin{array}{l}\text { Degrees of } \\
\text { freedom }\end{array}$ & Probability \\
\hline $\begin{array}{l}R . \text { procerus } . \\
R . \text { calvatus } \cdot \\
R . \text { laciniatus } \\
R . \text { laciniatus (with families } 82 \text { and } \\
\quad 88 \text { omitted) }\end{array}$ & $\begin{array}{l}10.42 \\
14.44 \\
35.28 \\
17.17\end{array}$ & $\begin{array}{r}13 \\
9 \\
12 \\
10\end{array}$ & $\begin{array}{c}0.7-0.5 \\
0.2-0.1 \\
<0.001 \\
0.1-0.05\end{array}$ \\
\hline
\end{tabular}

TABLE 3

Values of $\alpha$ for the ${ }_{3} F_{2}$ progenies

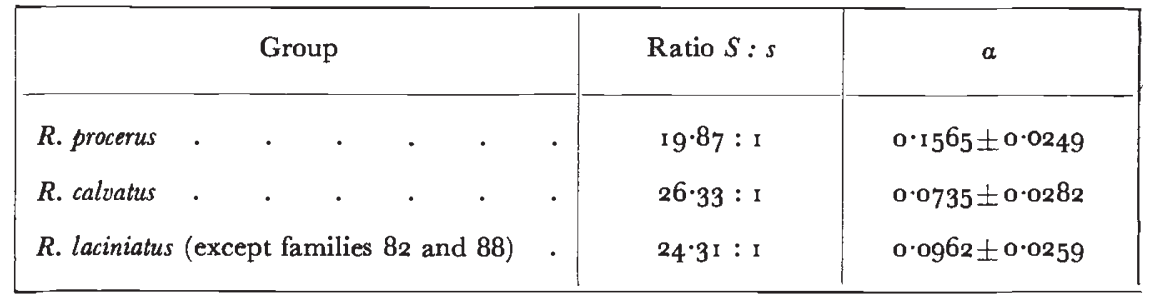


A comparison of the values of $\alpha$ obtained in this experiment with those obtained by Catcheside (1956, 1959) showed them to be intermediate between the sugary- 1 locus in tetraploid maize at the lower end and the $r$ locus in tomato at the upper end of the range.

\section{CONCLUSIONS}

If families 82 and 88 are omitted, the results of these experiments support the earlier work of Grane and Darlington in so far as the ratios obtained approximate more closely to the $20.8:$ I predicted on the basis of "chromatid segregation".

Taken as a whole the $\mathrm{F}_{2}$ progenies are homogeneous within crosses, provided families 82 and 88 are excluded. The reasons for these two families being so deficient in thornless individuals cannot be determined exactly at present, but it could be attributable to inviability, linkage to a lethal, or visual mis-classification due to the dark colour of $R$. laciniatus and its hybrids masking the manifestation of the glands on the cotyledons.

TABLE 4

$\chi^{2}$ analysis for a $20 \cdot 8: 1$ ratio after omission of families 82 and 88

\begin{tabular}{|c|c|c|c|c|c|c|}
\hline \multicolumn{4}{|c|}{ Item } & D.F. & $x^{2}$ & P. \\
\hline \multicolumn{2}{|c|}{$\begin{array}{l}R . \text { procerus . } \\
R . \text { calvatus . } \\
R . \text { laciniatus }\end{array}$} & : & : & $\begin{array}{l}\text { I } \\
\text { I } \\
\text { I }\end{array}$ & $\begin{array}{l}0.33 \\
5.37 \\
2 \cdot 99\end{array}$ & $\begin{array}{l}0.70-0.50 \\
0.05-0.02 \\
0.10-0.05\end{array}$ \\
\hline \multicolumn{2}{|r|}{ Total } & . & . & 3 & $8 \cdot 69$ & $\ldots$ \\
\hline \multicolumn{3}{|c|}{$\begin{array}{l}\text { (b) Overall ratio } \\
\text { Heterogeneity }\end{array}$} & $\dot{.}$ & $\begin{array}{l}1 \\
2\end{array}$ & $\begin{array}{l}3 \cdot 67 \\
5 \cdot 02\end{array}$ & $\begin{array}{l}0.10-0.05 \\
0.10-0.05\end{array}$ \\
\hline & Total & . & . & 3 & $8 \cdot 69$ & $\ldots$ \\
\hline
\end{tabular}

The fact that the $R$. calvatus and $R$. laciniatus groups (except families 82 and 88 ) have similar values of $\alpha$ clearly indicates that the meiotic behaviour of the chromosomes is the same in these two crosses, at least as far as the present data go. The $R$. procerus group, on the other hand, gives a significantly higher value for $\alpha$. This can mean either that chiasmata form more often between the centromere and the $s$ gene, or multivalent formation is more regular and more nearly complete in this cross. Discrimination between these two alternatives, however, rests ultimately on cytological analysis. If the former proves to be correct then genetic control of the distribution and frequency of chiasma will have been demonstrated. Genotypic control of chiasma distribution and frequency has been found by Rees (r955) in rye. He was able to show that significant differences existed between various inbred lines, but not generally between sub-lines within these lines. However, the demonstration of genotypic control in Rubus depends on the assumption that for all species the physical distance between the $s$ gene and the centromere is the same; an assumption which will hold only in the absence of an inversion carrying the $s$ gene.

Acknowledgment.-We wish to thank Professor K. Mather, F.R.s., for his suggestions in the interpretation of the data. 


\title{
4. REFERENCES
}

CATChEsIDE, D. G. I956. Double reduction and numerical non-disjunction in tetraploid maize. Heredity, Io, 205-2 I 8.

CATCheside, D. G. I959. Segregation in tetraploid potatoes. Heredity, 13, 403-407. CRANE, M. B., AND DARLINGTON, C. D. I932. Chromatid segregation in tetraploid Rubus. Nature, 129, 869.

FISHER, R. A., AND MATHER, K. I943. The inheritance of style length in Lythrum salicaria. Ann. Eugen., 12, I-23.

LEWIS, D. 1939. Genetical studies in cultivated raspberries. I. Inheritance and linkage. 7. Genet., $38,367-379$.

MAther, K. 1936. Segregation and linkage in autotetraploids. F. Genet., 32, 287-3 I4.

MATHER, K. 1951. The Measurement of Linkage in Heredity. Methuen, London.

REES, H. 1955. Genotypic control of chromosome behaviour in rye. I. Inbred lines. Heredity, 9, 93-I 15.

\section{GENIC CONTROL OF ANEUPLOIDY IN PENNISETUM}

\author{
P. GILDENHUYS and K. BRIX \\ Department of Genetics, University of Natal, Pietermaritzburg, \\ South Africa
}

\section{INTRODUCTION}

Received r 9.iv.6r

Perennial Pennisetum dubium is an irregular high polyploid in which chromosome numbers vary from 14 to 84 in root tips, 47 to 74 at $\mathrm{MI}$ and 9 to 37 at MII. This variation, which occurs from cell to cell in the same root tip or anther, has been shown to be the result of various mitotic and meiotic abnormalities which are under genetic control. The single perennial hybrid plant, produced from crosses between this species and the regular annual diploid $P$. typhoides $(2 n=14)$, has only 21 chromosomes (Gildenhuys and Brix, 1958).

The mitotic behaviour of the 2 I chromosomes of this sterile hybrid is nearly normal, but when attempts were made to double the complement by colchicine treatment, abnormalities occurred which give further evidence of genetic control of aneuploidy.

Although many different techniques were employed in attempting to double the chromosome number of the hybrid, none was successful. This was unexpected, since neither Krishnaswamy and Raman (1954) nor ourselves, using different techniques, had great difficulty in obtaining amphidiploids from the hybrid $P$. typhoides $(2 n=14) \times P$. purpureum $(2 n=28)$. When it became evident that the hybrid between $P$. typhoides and $P$. dubium was reacting differently to colchicine from that between $P$. typhoides and $P$. purpureum, identical treatments were applied to each hybrid to try to determine the nature of the difference between the two.

\section{METHODS}

Two or three cuttings, each consisting of two to three nodes, were taken from the lower part of mature tillers. These cuttings were totally immersed in a 0.0 I per cent. aqueous solution of colchicine for 3 days and then washed and placed in a 